\title{
SISTEM INFORMASI MONITORING DAN EVALUASI BELAJAR SISWA BERBASIS WEB DAN SMS GATEWAY DI SDIT NURUL ISTIQLAL KLATEN
}

\author{
Salisa Kurnia Sari ${ }^{1)}$, Dwi Remawati ${ }^{2)}$, Bebas Widada ${ }^{3)}$ \\ ${ }^{1)}$ Program Studi Sistem Informasi, STMIK Sinar Nusantara Surakarta \\ ${ }^{2)}$ Program Studi Teknik Informatika, STMIK Sinar Nusantara Surakarta \\ ${ }^{3)}$ Program Studi Sistem Informasi, STMIK Sinar Nusantara Surakarta \\ 1) salisasila@gmail.com, ${ }^{2}$ dwirema@gmail.com, ${ }^{3)}$ bbswdd@yahoo.com
}

\begin{abstract}
Nurul SDIT Istiqlal Klaten an Islamic-based elementary school that has a high awareness of the importance of the monitoring and evaluation of student learning in order to know the level of success of the learning process is running. In order to maximize the process it created an information system of monitoring and evaluation of student learning web-based and SMS-gateway. This information system can display a list of values of each student in each subject and grade of teaching a teacher with grouping based on the criteria of the KKM. Moreover, it can display a graph of the percentage of the value of grouping results. Values that have been added can be disseminated to parents / guardians of the students. This information system will display a graph the value of each student for all four test scores. System design using the Context Diagram, Hierarchy Process Input Output, Data Flow Diagrams, input design, output design, and database design. The result of this research is the information system of monitoring and evaluation of student learning which has an input in the form of student data, teacher data subject, the data homeroom, the data subject, class data, the data teacher, materials, values and information. While the results of the output of a graph of the results of grouping value, sms information listed value value with KKM and the average grade and disseminated the text contains some information. Based on the calculation of the questionnaire, obtained persentase $84,00 \%$ so that it can be concluded that the information system is feasible to implemention in SDIT Nurul Istiqlal Klaten.
\end{abstract}

Keywords: Monitoring, PHP, SMS-Gateway

\section{PENDAHULUAN}

Dalam dunia pendidikan kegiatan monitoring dan evaluasi memiliki peranan yang sangat penting. Seperti layaknya lembaga pendidikan lain yang menerapkan kegiatan monitoring dan evaluasi terhadap peseta didik. Walaupun SDIT Nurul Istiqlal Klaten menerapkan kurikulum KTSP namun juga tetap melakukan kegiatan monitoring dan evaluasi dengan melaksanakan ulangan secara berkala sehingga dapat diketahui pencapaian dari proses belajar mengajar yang telah dilakukan. Kendala yang ada adalah belum adanya sarana yang dapat membantu dalam proses monitoring dan evaluasi belajar siswa.

Berdasarkan permasalahan tersebut, penulis membuat sistem informasi untuk memonitoring proses belajar mengajar berdasarkan hasil evaluasi belajar. Sistem ini akan menampilkan informasi hasil ulangan siswa untuk mata pelajaran dan kelas yang diampu guru. Sistem juga dapat menyebarkan nilai hasil ulangan dengan mengirimkan informasi nilai kepada orangtua/ wali. 
Diharapkan dengan adanya aplikasi ini, keberhasilan dalam penyampaian materi sebisa mungkin dapat terkontrol.

\section{METODE PENELITIAN}

Metode penelitian yang dilakukan adalah dengan menggabungkan data primer serta data sekunder. Sedangkan metode pengumpulan data dilakukan dengan wawancara, observasi serta studi pustaka. Teknik penelitian adalah dengan analisa dan desain sistem, analisa kebutuhan sistem, perancangan sistem, dengan membuat diagram alir data, diagram konteks, diagram HIPO, dan Data Flow Diagram(DFD) Level 0,1 serta relasi tabel untuk mengetahui relasiantar tabel dalam sistem, desain teknologi untuk menentukan kebutuhan hardware dan software.

\section{TINJAUAN PUSTAKA}

\subsection{Monitoring}

Monitoring adalah proses pengumpulan dan analisis informasi berdasarkan indikator yang ditetapkan secara sistematis dan berkelanjutan tentang kegiatan/program sehingga dapat dilakukan tindakan koreksi untuk penyempurnaan program/kegiatan itu selanjutnya. (Soekartawi, 2006)

\subsection{Sistem Informasi}

Sistem informasi merupakan komponen yang saling bekerja sama untuk mengumpulkan, mengolah, menyimpan dan menyebarkan informasi untuk mendukung pengambilan keputusan, koordinasi, pengendalian, analisis masalah dan visualisasi dalam sebuah organisasi . (Laudon \& Jane, 2010)

\subsection{Website}

Website atau situs merupakan kumpulan yang luas dari jaringan komputer besar dan kecil yang saling berhubungan menggunakan jaringan komunikasi yang ada di seluruh dunia. Seluruh manusia yang secara aktif berpartisipasi sehingga internet menjadi sumber daya informasi yang sangat berharga. (Yuhefizar, 2013)

\subsection{Analisa Sistem}

Analisa Sistem adalah fase pengembangan sistem yang menentukan sistem informasi apa yang harus dilakukan untuk memecahkan masalah yang sudah ada dengan mempelajari sistem dan proses kerja untuk mengidentifikasi kekuatan, kelemahan, dan peluang untuk perbaikan . (Stair \& Reynolds, 2010)

\subsection{Basis Data}

Basis data adalah kumpulan data yang saling berhubungan secara logikal serta deskripsi dari data tersebut, yang dirancang untuk memenuhi kebutuhan informasi suatu organisasi. (Connolly \& Begg, 2010)

\subsection{Desain Informasi}

Desain sistem adalah teknik pemecahan masalah yang saling melengkapi (untuk analisis sistem) yang merakit kembali potongan komponen sistem 
menjadi sistem yang lengkap-dengan mengharapkan peningkatan sistem . (Whitten, Lonnie, \& Bentley, 2009)

\subsection{Context Diagram (CD)}

Context Diagram (CD)adalah sebuah diagram sederhana yang menggambarkan hubungan antara entity luar, masukan dan keluaran dari sistem. Diagram konteks direpresentasikan dengan lingkaran tunggal yang mewakili keseluruhan sistem. (Fathansyah, 2012)

\subsection{Data Flow Diagram (DFD)}

DFD adalah representasi grafik yang menggambarkan aliran informasi dan transformasi informasi yang diaplikasikan sebagai data yang mengalir dari masukan (input) dan keluaran(output) . (Fathansyah, 2012)

\section{HASIL DAN PEMBAHASAN}

\subsection{Context Diagram (CD)}

Context Diagram hubungan sistem dengan entitas luar yang terlibat langsung dengan sistem ini seperti pada Gambar 1.

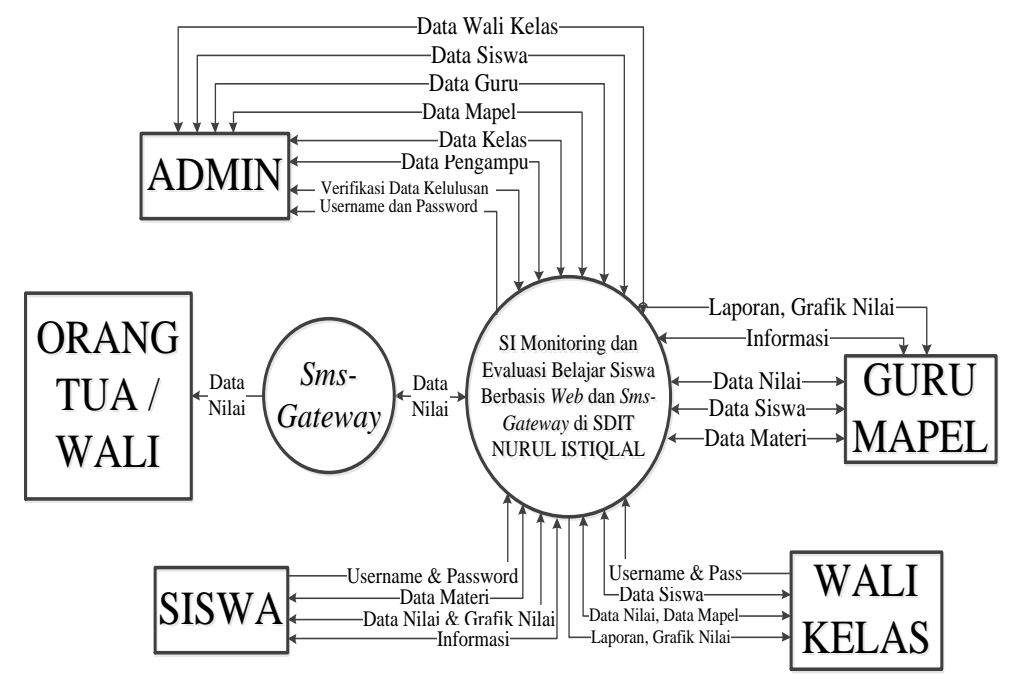

Gambar 1. Context Diagram

Pada Gambar 1 Admin dapat melihat data wali kelas, guru, mapel, pengampu, melakukan varifikasi kelulusan. Guru mapel dapat menambahkan materi, nilai, mencetak nilai, dan melihat grafik. Wali kelas dapat melihat daftar siswa pada kelas tertentu, materi dan nilai. Wali kelas dapat mencetak nilai dan melihat grafik nilai. Siswa dapat melihat materi dan nilai serta melihat grafik nilai. Orang tua dapat menerima pesan singkat melalui layanan sms gateway berisi nilai ulangan dan informasi.

\subsection{DFD Level 0}

Sistem ini terdapat 11 proses yaitu manajemen data siswa, guru, mapel, kelas, pengajar, materi, nilai, informasi, sms-gateway, verifikasi data kelulusan dan data wali kelas. 
Pada Gambar 2 Admin melakukan manajemen data siswa, guru, kelas, mapel, pengajar dan verifikasi kelulusan. Siswa melakukan proses manajemen data siswa untuk fitur ganti password. Guru mapel memanajemen materi, nilai, serta smsgateway. Wali kelas dapat melihat data siswa, mapel dan nilai ulangan siswa pada kelas tertentu. Orangtua mendapatkan data informasi nilai ulangan siswa.

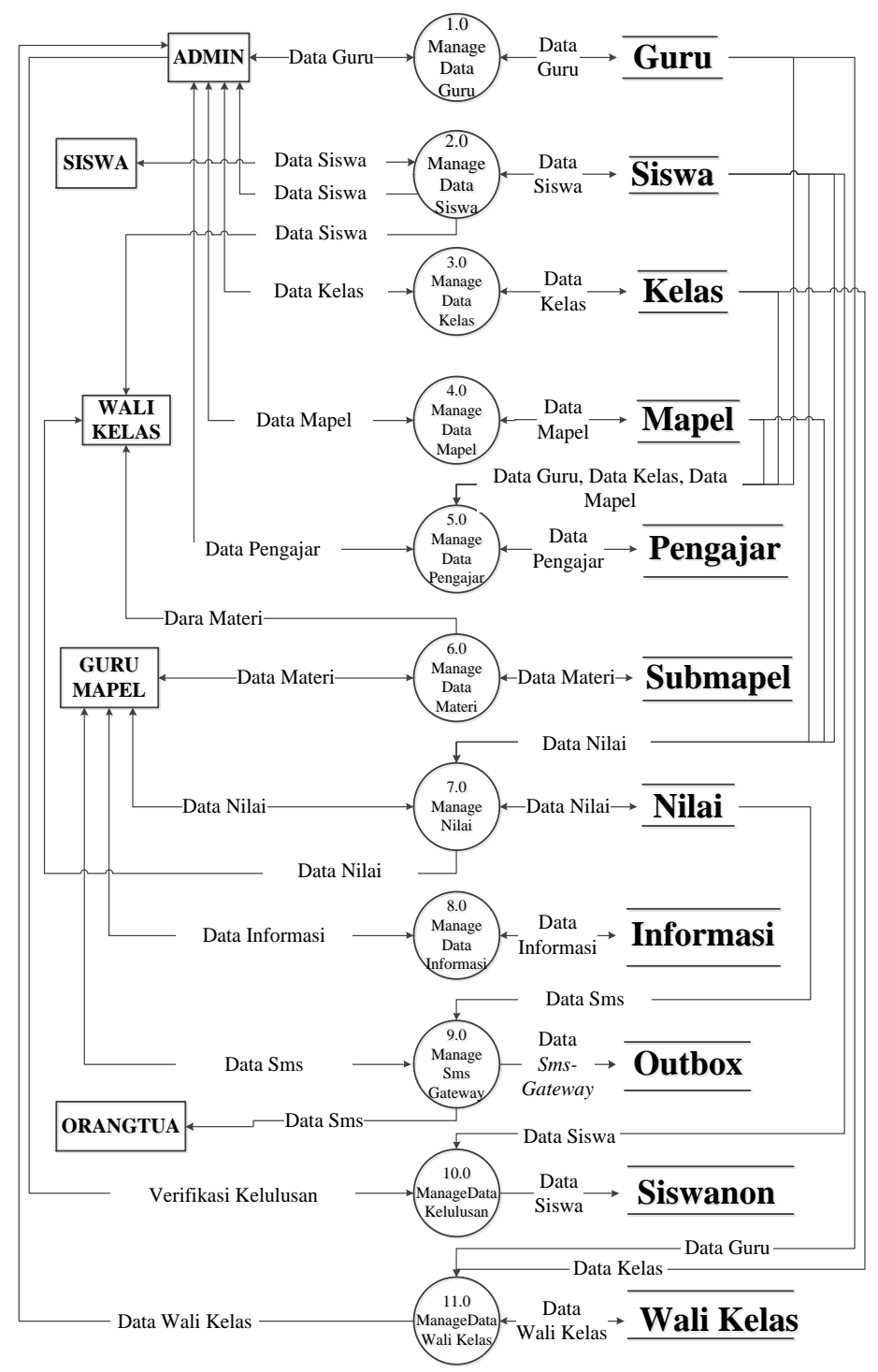

Gambar 2. DFD Level 0

\subsection{DFD Level 1}

\subsubsection{DFD Level 1 Proses 1}

Proses 1 adalah manajemen data guru yang dilakukan admin seperti pada Gambar 3. Data guru ditambahkan oleh admin. Guru Mapel dapat mengubah password. Pada Gambar 3 Admin dapat menghapus data guru. Dan kemudian melihat daftar data guru. 


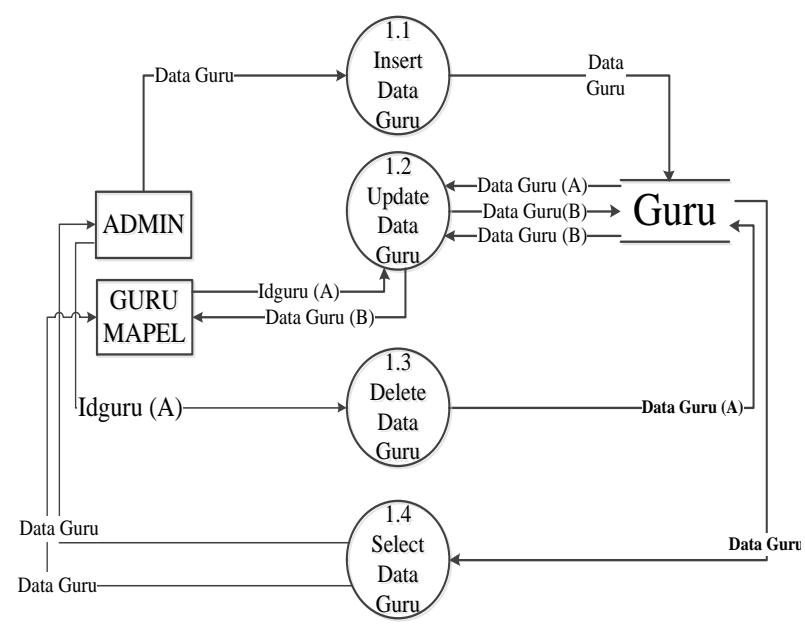

Gambar 3. DFD Level 1 Proses Manajemen Data Guru

\subsubsection{DFD Level 1 Proses 2}

Proses 2 adalah manajemen data siswa yang dilakukan admin. Pada Gambar 4 Admin menambahkan data siswa yang berelasi dengan tabel kelas. Siswa dapat mengubah password. Wali kelas dapat melihat daftar siswa berdasarkan kelas tertentu.

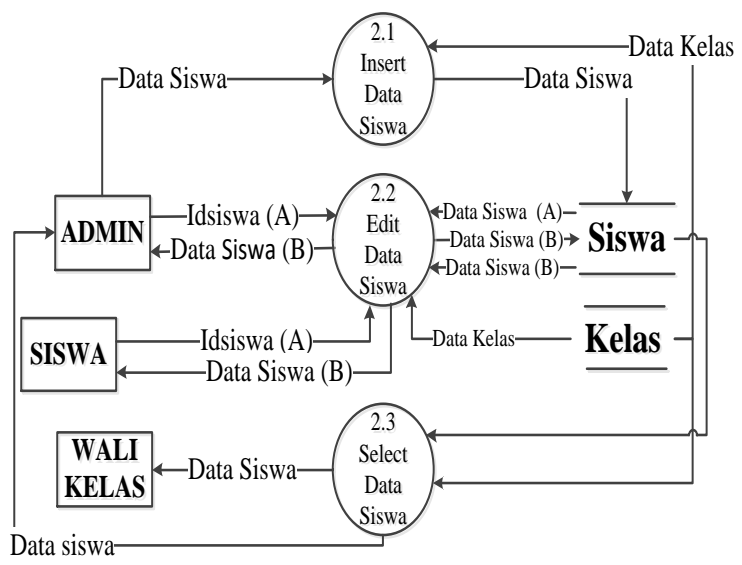

Gambar 4. DFD Level 1 Proses Manajemen Data Siswa

\subsubsection{DFD Level 1 Proses 3}

Proses 3 adalah manajemen data kelas yang dilakukan admin. Pada Gambar 5 Admin menambahkan data kelas. Kemudian admin dapat memperbaharui data kelas dan menghapus data kelas. Selanjutnya data dapat dilihat oleh admin.

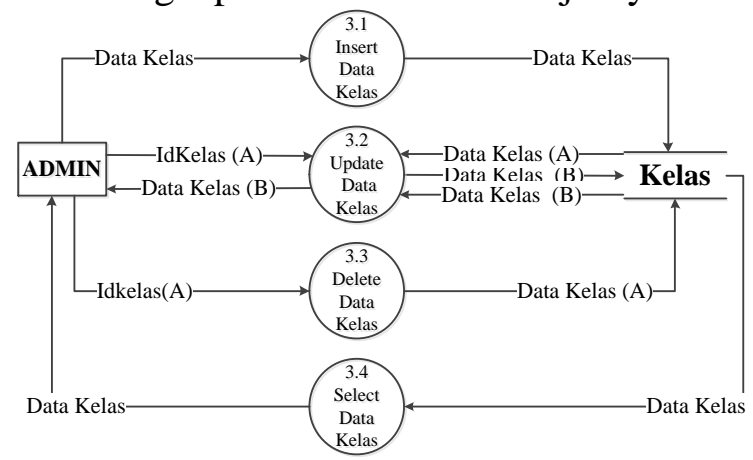

Gambar 5. DFD Level 1 Proses Manajemen Data Kelas 


\subsubsection{DFD Level 1 Proses 4}

Proses 4 adalah manajemen data mapel yang dilakukan admin. Pada Gambar 6. Admin menambahkan data mapel, memperbaharui data mapel dan menghapus data mapel. Wali kelas dan admin dapat melihat daftar mapel yang ada.

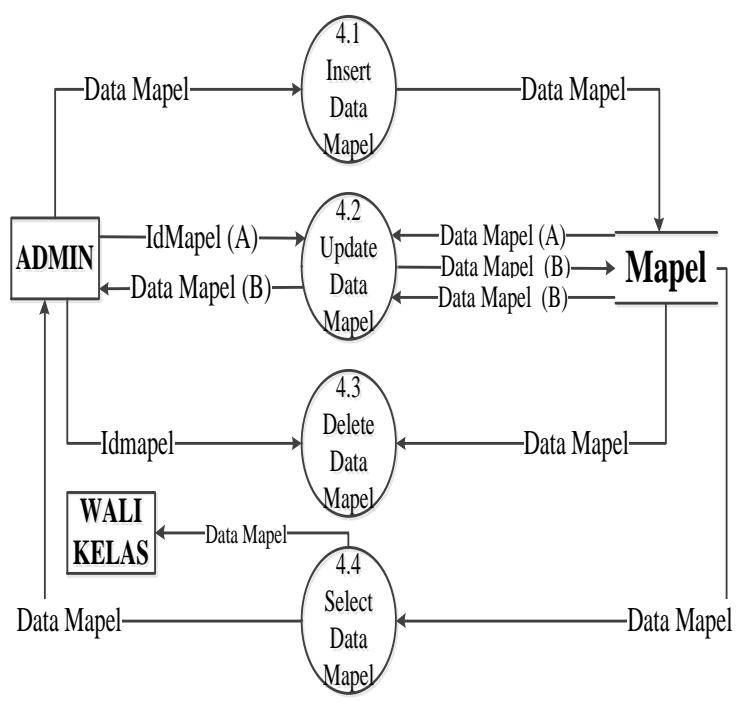

Gambar 6. DFD Level 1 Proses Manajemen Data Mapel

\subsection{Relasi Antar Tabel}

Relasi antar tabel dapat ditunjukkan pada Gambar 7 sebagai berikut :

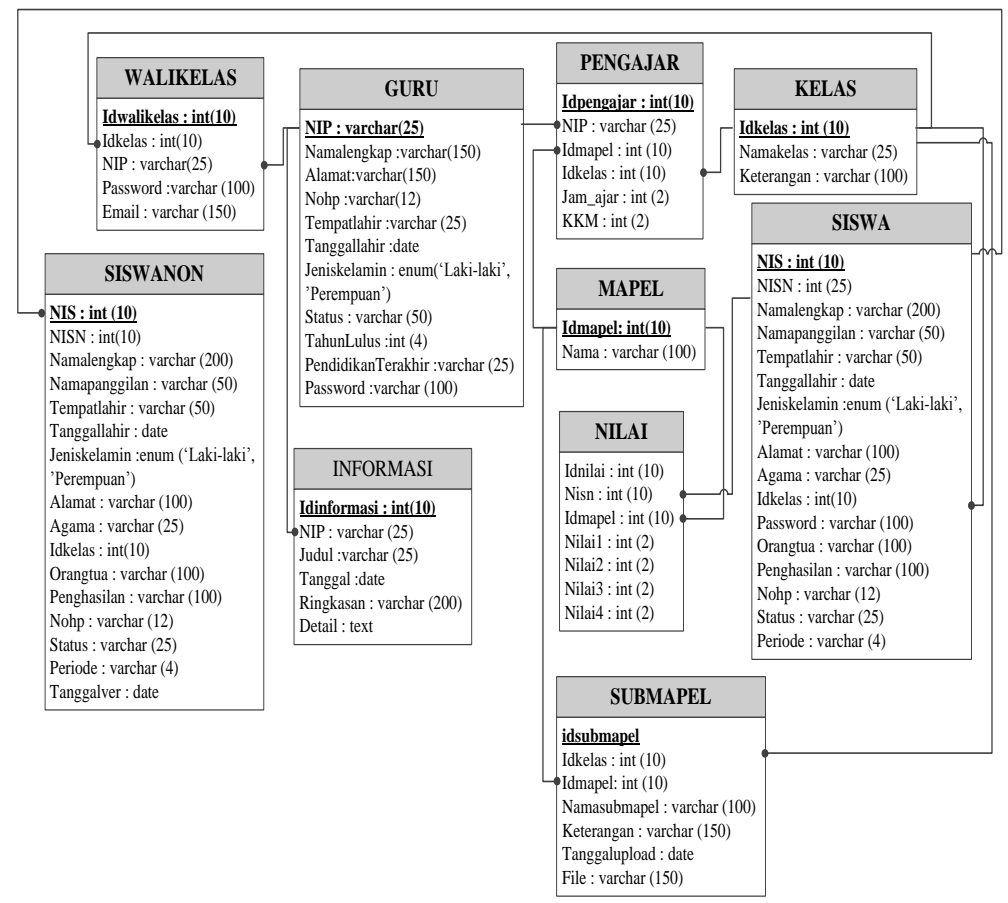

Gambar 7. Relasi Antar Tabel 


\subsection{Implementasi}

Pada Gambar 8 User yang melakukan login dengan username "Admin" dan password yang telah ditentukan maka akan masuk ke halaman Admin. Admin melakukan manajemen data siswa, guru, kelas, mapel dan data pengajar.

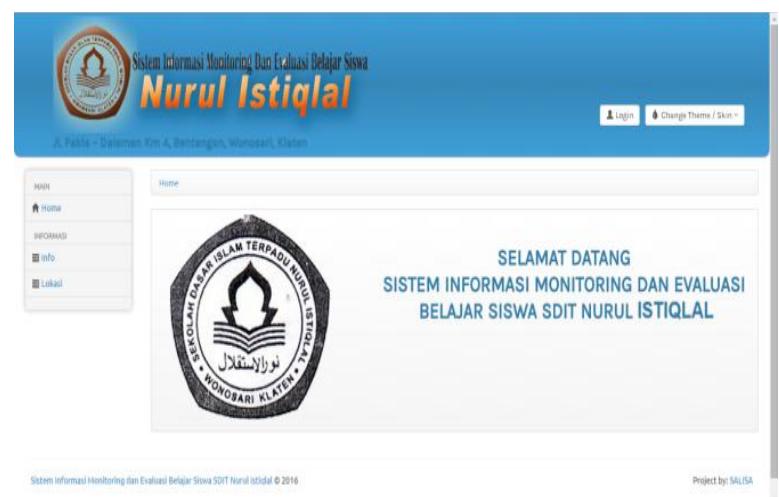

Gambar 8. Implementasi Halaman Index

Pada Gambar 9 Selain menambahkan data, admin juga dapat memperbaharui data yang ada. Pada Gambar 10 Admin juga dapat menghapus data- data yang telah ditambahkan.

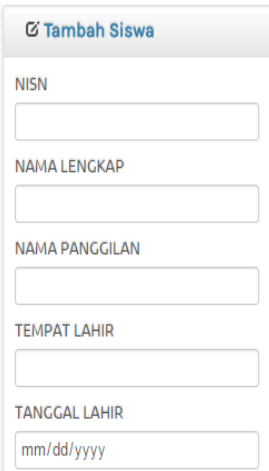

Gambar 9 Form Tambah Data Siswa

\begin{tabular}{l} 
C Edit Siswa \\
NISN \\
9878836 \\
NAMA LENGKAP \\
Nabila Isnaini R \\
NAMA PANGGILAN \\
Nana \\
TEMPAT LAHIR \\
Klaten \\
TANCGAL LAHIR \\
09/09/2006 \\
\hline
\end{tabular}

Gambar 10 Form Edit Data Siswa 
Jika user melakukan login dengan username "NIP" dan password yang telah ditentukan maka akan masuk ke halaman guru mapel. Pada Gambar 11 Guru mapel dapat menambahkan data materi berdasarkan kelas dan mapel yang diajar. Guru mapel dapat menunggah file materi.

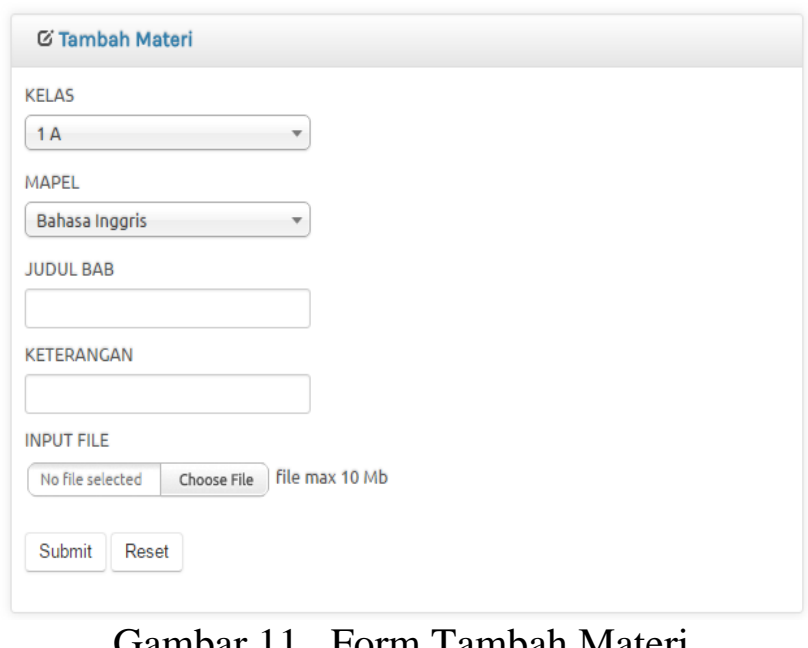

Gambar 11. Form Tambah Materi

Pada Gambar 12 Terdapat juga fasilitas import nilai melalui file excel.

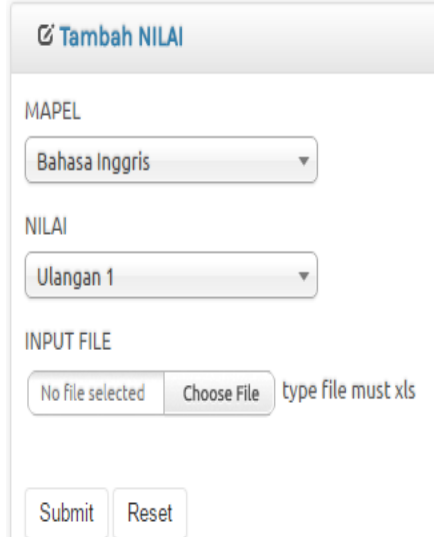

Gambar 12. Form Tambah Nilai Import Excel

Pada Gambar 13 Untuk melakukan monitoring nilai siswa, guru dapat melihat daftar nilai siswa berdasarkan kelas, mapel dan periode ulangan yang dipilih. Pada daftar nilai ditunjukkan nilai siswa yang kurang dari atau sama dengan KKM dengan tulisan warna merah dan yang lebih dari KKM dengan tulisan warna hitam. Terdapat juga nilai rata- rata kelas untuk masing- masing mata pelajaran. 


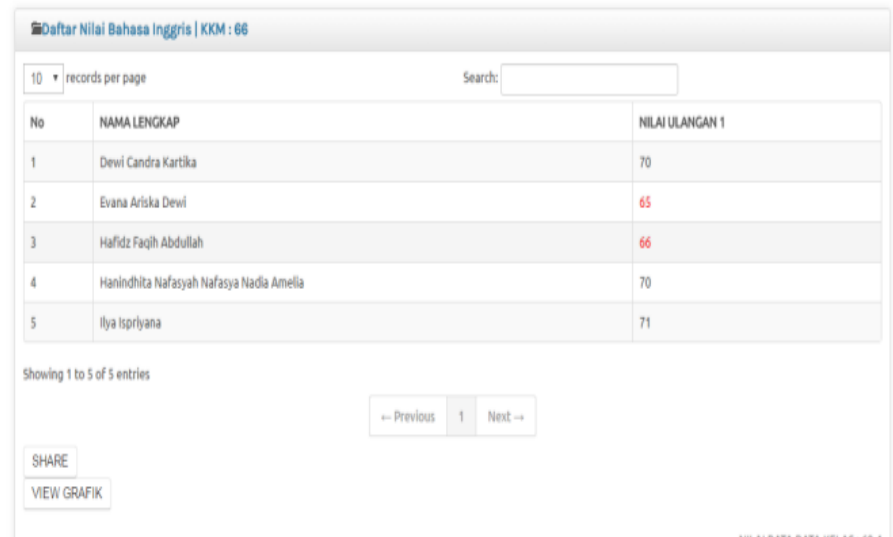

Gambar 13. Form Daftar Nilai

Pada Gambar 14 menunjukkan Guru dapat menyebarkan informasi kepada orangtua/ wali murid dengan maksimal 160 karakter.

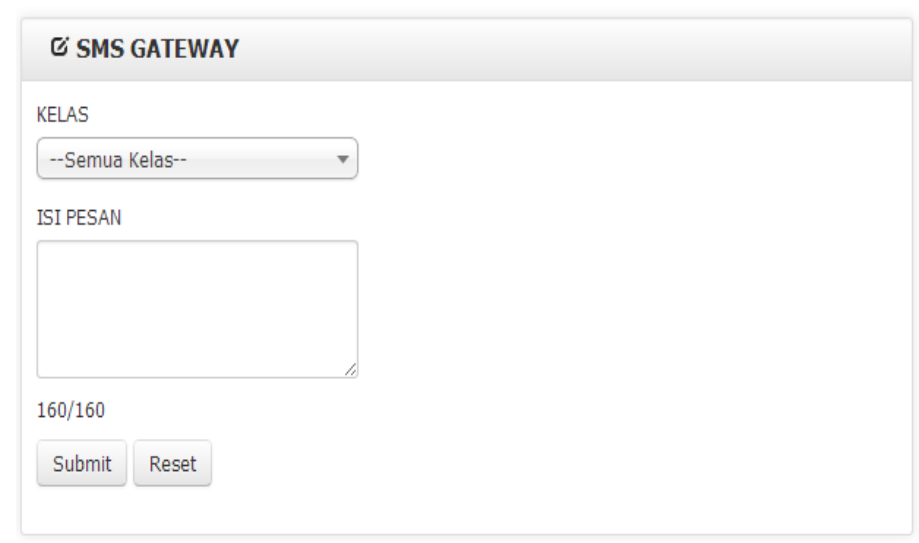

Gambar 14. Form SMS

Pada Gambar 15 adalah contoh sms yang dikirimkan kepada orangtua yang mana berisi nama siswa, mapel serta nilai ulangan yang dipilih. Pada pesan tersebut dilengkapi juga informasi nilai KKM dan nilai rata- rata kelas.

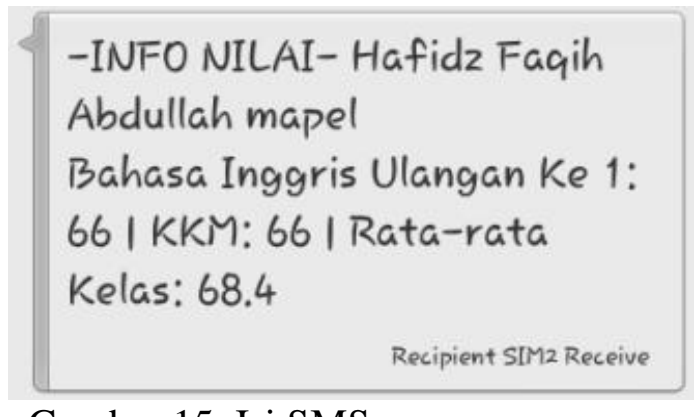

Gambar 15. Isi SMS

Pada Gambar 16 menunjukkan Sistem juga dapat mengirimkan nilai hasil semua ulangan dengan disertai nilai KKM dan rata- rata kelas. 


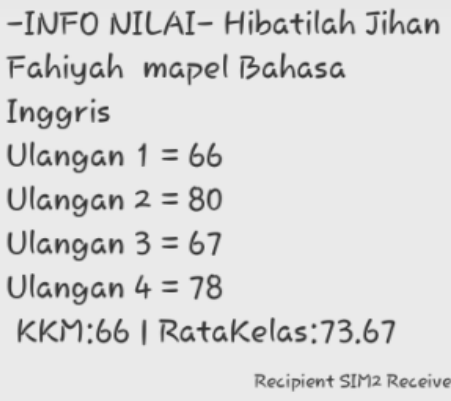

\section{Gambar 16.Isi SMS Semua Ulangan}

Gambar 17 menunjukkan bahwa Guru dapat menyebarkan informasi kepada orangtua/ wali secara serentak.

$$
\begin{aligned}
& \text { Assalamualaikum } \\
& \text { Dibertahukan kepada orang } \\
& \text { tua/ wali murid, hari Sabtu } \\
& \text { minggu ke-3 diadakan rapat } \\
& \text { pembangunan gedung baru. } \\
& \text { Recipient SIM2 Receive }
\end{aligned}
$$

\subsection{Pengujian BlackBox}

\begin{tabular}{|c|c|c|c|}
\hline \multicolumn{4}{|c|}{ Kasus dan Hasil Uji (Data Benar) } \\
\hline Data Masukan & Yang Diharapkan & Pengamatan & Kesimpulan \\
\hline $\begin{array}{l}\text { Klik menu Materi } \\
\text { (Guru) }\end{array}$ & $\begin{array}{l}\text { Menampilkan data } \\
\text { materi yang ada di } \\
\text { database. }\end{array}$ & $\begin{array}{l}\text { Dapat menampilkan } \\
\text { data materi yang } \\
\text { ada di database. }\end{array}$ & $\begin{array}{l}{[\sqrt{ }] \text { Diterima }} \\
{[\quad] \text { Ditolak }}\end{array}$ \\
\hline $\begin{array}{l}\text { Klik menu Tambah Data } \\
\text { (Guru) }\end{array}$ & $\begin{array}{l}\text { Menampilkan form } \\
\text { menambah data materi }\end{array}$ & $\begin{array}{l}\text { Menampilkan form } \\
\text { menambah data } \\
\text { materi }\end{array}$ & $\begin{array}{l}{[\sqrt{ }] \text { Diterima }} \\
{[\quad] \text { Ditolak }}\end{array}$ \\
\hline $\begin{array}{l}\text { Klik View pada data } \\
\text { materi } \\
\text { (Guru) }\end{array}$ & $\begin{array}{l}\text { Menampilkan detail } \\
\text { dari materi }\end{array}$ & $\begin{array}{l}\text { Menampilkan detail } \\
\text { dari materi }\end{array}$ & $\begin{array}{l}{[\sqrt{ }] \text { Diterima }} \\
{[\quad] \text { Ditolak }}\end{array}$ \\
\hline $\begin{array}{l}\text { Klik Download data } \\
\text { materi } \\
\text { (Guru) }\end{array}$ & $\begin{array}{l}\text { Melakukan proses } \\
\text { download dari materi }\end{array}$ & $\begin{array}{l}\text { Melakukan proses } \\
\text { download dari } \\
\text { materi }\end{array}$ & $\begin{array}{l}{[\sqrt{ }] \text { Diterima }} \\
{[\quad] \text { Ditolak }}\end{array}$ \\
\hline $\begin{array}{l}\text { Klik Edit Materi } \\
\text { (Guru) }\end{array}$ & $\begin{array}{l}\text { Menampilkan form edit } \\
\text { materi }\end{array}$ & $\begin{array}{l}\text { Menampilkan form } \\
\text { edit materi }\end{array}$ & $\begin{array}{l}{[\sqrt{ }] \text { Diterima }} \\
{[\quad] \text { Ditolak }}\end{array}$ \\
\hline $\begin{array}{l}\text { Klik Hapus Materi } \\
\text { (Guru) }\end{array}$ & $\begin{array}{l}\text { Menghapus data materi } \\
\text { yang ada di database } \\
\text { sesuai dengan idmateri } \\
\text { yang dipilih. }\end{array}$ & $\begin{array}{l}\text { Menghapus data } \\
\text { materi yang ada di } \\
\text { database sesuai } \\
\text { dengan idmateri } \\
\text { yang dipilih. }\end{array}$ & $\begin{array}{l}{[\sqrt{ }] \text { Diterima }} \\
{[\quad] \text { Ditolak }}\end{array}$ \\
\hline
\end{tabular}

\section{Gambar 17. Isi SMS}

Pengujian blackbox adalah pengujian pada sebuah sistem dimana lebih menitik beratkan pada kesesuaian eksekusi sistem dengan yang diharapkan. Berikut adalah pengujian blackbox pada sistem ini.

Tabel 1.Pengujian Menu Materi 


\begin{tabular}{|c|c|c|c|}
\hline \multicolumn{4}{|c|}{ Kasus dan Hasil Uji (Data Benar) } \\
\hline Data Masukan & Yang Diharapkan & Pengamatan & Kesimpulan \\
\hline $\begin{array}{l}\text { Klik Materi } \\
\text { (Siswa) }\end{array}$ & $\begin{array}{l}\text { Menampilkan materi } \\
\text { dari setiap mapel yang } \\
\text { diikuti siswa. }\end{array}$ & $\begin{array}{l}\text { Menampilkan } \\
\text { materi dari setiap } \\
\text { mapel yang diikuti } \\
\text { siswa. }\end{array}$ & $\begin{array}{l}{[\sqrt{ }] \text { Diterima }} \\
{[] \text { Ditolak }}\end{array}$ \\
\hline $\begin{array}{l}\text { Klik View pada data } \\
\text { materi } \\
\text { (Siswa) }\end{array}$ & $\begin{array}{l}\text { Menampilkan detail } \\
\text { dari materi }\end{array}$ & $\begin{array}{l}\text { Menampilkan detail } \\
\text { dari materi }\end{array}$ & $\begin{array}{l}{[\sqrt{ }] \text { Diterima }} \\
{[\quad] \text { Ditolak }}\end{array}$ \\
\hline $\begin{array}{l}\text { Klik Download data } \\
\text { materi } \\
\text { (Siswa) }\end{array}$ & $\begin{array}{l}\text { Melakukan proses } \\
\text { download dari materi }\end{array}$ & $\begin{array}{l}\text { Melakukan proses } \\
\text { download dari } \\
\text { materi }\end{array}$ & $\begin{array}{l}{[\sqrt{ }] \text { Diterima }} \\
{[\quad] \text { Ditolak }}\end{array}$ \\
\hline \multicolumn{4}{|c|}{ Kasus dan Hasil Uji (Data Salah) } \\
\hline Data Masukan & Yang Diharapkan & Pengamatan & Kesimpulan \\
\hline $\begin{array}{l}\text { Melakukan input materi } \\
\text { tidak pada kelas dan } \\
\text { mapel yang diajar }\end{array}$ & $\begin{array}{l}\text { Menampilkan pesan } \\
\text { kesalahan "Anda tidak } \\
\text { mengajar kelas ini” }\end{array}$ & $\begin{array}{l}\text { Menampilkan pesan } \\
\text { kesalahan "Anda } \\
\text { tidak mengajar } \\
\text { kelas ini" }\end{array}$ & $\begin{array}{l}{[\sqrt{ }] \text { Diterima }} \\
{[\quad] \text { Ditolak }}\end{array}$ \\
\hline $\begin{array}{l}\text { Upload materi dengan } \\
\text { ukuran yang sangat besar }\end{array}$ & $\begin{array}{l}\text { Tidak dapat melakukan } \\
\text { upload materi }\end{array}$ & $\begin{array}{l}\text { Tidak dapat } \\
\text { melakukan upload } \\
\text { materi }\end{array}$ & $\begin{array}{l}{[\sqrt{ }] \text { Diterima }} \\
{[\quad] \text { Ditolak }}\end{array}$ \\
\hline
\end{tabular}

\section{KESIMPULAN DAN SARAN}

\subsection{Kesimpulan}

Kesimpulan yang dapat diperoleh dari Sistem Informasi Monitoring dan Evaluasi Belajar Siswa Berbasis Web dan SmsGateway ini adalah sebagai berikut ini :

1. Sistem Informasi Monitoring dan Evaluasi Belajar Siswa di SDIT Nurul Istiqlal ini digunakan sebagai sarana pendukung dalam proses monitoring dan evaluasi belajar siswa.

2. Sistem Informasi Monitoring dan Evaluasi Belajar Siswa di SDIT Nurul Istiqlal ini juga berfungsi sebagai portal antara guru mapel, wali kelas, siswa serta orangtua sehingga dapat sebagai media dalam memantau proses belajar mengajar.

3. Sistem Informasi Monitoring dan Evaluasi Belajar Siswa di SDIT Nurul Istiqlal ini membantu guru mapel dan wali kelas untuk melihat pencapaian siswa melalui grafik nilai. Dan dapat mencetak daftar nilai siswa.

4. Berdasarkan hasil perhitungan kuesioner diperoleh persentase $84,00 \%$, sehingga dapat disimpulkan bahwa sistem layak untuk diimplementasikan di SDIT Nurul Istiqlal Klaten.

\subsection{Saran}

Untuk pengembangan pembuatan sistem ini dikemudian hari, maka perlu di berikan beberapa saran sebagai berikut ini :

1. Pada sistem ini, siswa hanya dapat melakukan download materi saja. Alangkah lebih baiknya ditambah dengan fasilitas upload tugas.

2. Sistem Informasi Monitoring dan Evaluasi Belajar Siswa di SDIT ini belum bisa menangani masalah pindah semester. Alangkah lebih baiknya dilengkapi dengan sistem pindah semester bahkan pindah kelas. 
3. Sistem Informasi Monitoring dan Evaluasi Belajar Siswa di SDIT ini belum terdapat fitur untuk membandingkan nilai semua kelas secara paralel. Alangkah lebih baiknya dilengkapi fitur tersebut.

\section{DAFTAR PUSTAKA}

Connolly, T., \& Begg, C. (2010). Database Systems: a practical approach to design, implementation, and management. 5th Edition. America: Pearson Education.

Fathansyah. (2012). Basis Data. Bandung: Informatika.

Laudon, K. C., \& Jane, P. L. (2010). Manajemen Information System :Managing the Digital Firm. New Jersey: Prentice-Hall.

Soekartawi. (2006). Monitoring Dan Evaluasi Proyek Pendidikan. Jakarta: Dunia Pustaka Jaya.

Stair, M. R., \& Reynolds, G. W. (2010). Principles of Information Systems: A Managerial Approach. (9th edition). Australia: Thomson Course Technology.

Whitten, J. L., Lonnie, D., \& Bentley. (2009). Systems Analysis and Design for The Global Enterprise Seventh Edition. New York: Mc. GrawHill.

Yuhefizar. (2013). Cara Mudah \& Murah Membangun \& Mengelola Website. Yogyakarta: Graha Ilmu. 